\title{
Sustainability transitions in the context of pandemic: an introduction to the focused issue on social innovation and systemic impact
}

\author{
Geoffrey Desa ${ }^{1} \cdot$ Xiangping Jia $^{2}$
}

Accepted: 13 July 2020 / Published online: 21 July 2020

○) Springer Nature B.V. 2020

\begin{abstract}
For society to achieve the Sustainable Development Goals, the agri-food industry needs a substantial sustainability transition toward food systems capable of delivering greater volumes of nutritious food, while simultaneously lowering the environmental footprint. This issue of AHV focuses on the big picture-on mechanisms of sustainability transition, from social innovation, to models of finance and institutional systems, and calls for business and agricultural researchers to transform the sector together. Contributors to this issue embrace a transdisciplinary outlook, including scientific, technical, social and political dimensions of agroecology. This issue is a call to action: to encourage the community of social entrepreneurs, ecosystem players and researchers to contribute analytical methods, experiences and scientific insights on emerging social innovations related to food, agriculture and rural-urban transformation.
\end{abstract}

Keywords Sustainability transition $\cdot$ Social innovation $\cdot$ Agroecology $\cdot$ Food $\cdot$ Agriculture

\section{Introduction}

The global agriculture and food industry has an enormous economic and environmental impact. Valued at $\$ 8$ trillion USD (van Nieukoop 2019) and employing over 1 billion people, ${ }^{1}$ the industry also accounts for approximately half of all land use, $70 \%$ of water use and one-quarter of global greenhouse gas emissions (IPCC 2019). For society to achieve the Sustainable Development Goals, the agri-food industry needs a substantial sustainability transition toward food systems capable of delivering greater volumes of more nutritious food, while simultaneously lowering the environmental footprint (FAO 2018; Hawken 2017). Despite this global imperative, the economic incentives are skewed against research and action. While large in real terms, the industry contributed less than $4 \%$ to global GDP (FAO 2019a). Public and private R\&D resources for food and land

Xiangping Jia

jia.xiangping@outlook.com

Geoffrey Desa

gdesa@sfsu.edu

San Francisco State University, San Francisco, CA, USA

2 Agricultural Information Institute, Chinese Academy of Agricultural Sciences, Beijing, China use systems together account for $0.1 \%$ of global GDP (FOLU 2019 , p. 171), with limited funds for open-source research (Heisey and Fugley 2018; FAO 2017). From the perspective of business researchers, the industry is a niche sector with limited potential for academic research. ${ }^{2}$ However, this view of a small, siloed research sector with limited investment importance, misses the big picture and a big opportunity. The industry is going through one of the greatest changes since the post-war period, with changing consumer preferences, technology enabled productivity improvements, and turmoil in domestic and international markets (Djanian and Ferreira 2020). To meet these challenges, researchers across multiple disciplines in agriculture and business need to identify food systems that work-systems in which food and agriculture are not mere niche sectors with marginal economic returns, but are key sources of social innovation, of economic and environmental survival. This is not merely an agricultural imperative but a global business imperative,

\footnotetext{
1 The food and agriculture industry is responsible for $26.89 \%$ of global employment World Bank (2020a), and employs over 1 billion people (Cassidy and Snyder 2019).

${ }^{2}$ A Web of Science literature review yields 608 articles which list "food", "agriculture" or"agri-food" in the title/abstract of the Financial Times Top 50 Business Research Journals (from 2000 to 2020). This, of approximately 59,669 articles published for the time period, indicating a sectoral focus of $1 \%$. For comparison, the search term "innovation", listed 6307 articles, a 10\% hit-rate.
} 
and the challenge of our day. This issue of AHV focuses on the big picture-on mechanisms of sustainability transition, from social innovation, to models of finance and institutional systems, and calls for business and agricultural researchers to transform the sector together.

The need for transdisciplinary research and action is felt with ever more urgency in light of the Covid-19 pandemic. Food security and nutrition (FSN), access to a living wage, access to a clean environment, availability of healthcare-all chronic social issues, have been further stressed for the poor and the vulnerable. From a global food systems perspective, the lock-down and social distancing phases have prompted many conversations (WFP 2020; FAO 2020a; GNR 2020; Houngbo 2020) on what sustainable food systems (SFS) will look like in a pandemic constrained, and post-pandemic world. By exacerbating social challenges, and adding complexity to the global food system the pandemic has renewed the focus on agroecological transitions - the "broad and varied processes of experimentation and innovation that often start in niches and have the potential of transforming the dominant agri-food system into a more sustainable one" (Buurma et al. 2017). For global food systems to transition toward sustainability, we need systems that encourage experimentation, innovation and transfer. However, research and policy on sustainability transitions in the food system suffer from three limitations: (a) niche perspectives on innovation, (b) functionalism, and (c) resource-dependencies, all of which limit the viability and longevity of such endeavors.

When food \& agriculture is viewed as a distinct, specialized sector, sustainability transition is interpreted as a sectoral and technical configuration, focused on interactions between inputs, outputs and the environments within that sector. Innovations focused on sustainability transition are treated as internal artefacts within existing regimes on food research and policy (HLPE 2020). Rather than tweaking the practices of unsustainable agricultural systems, what does it take to address the root causes of problems in an integrated way and provide holistic and long-term solutions? The FAO's primer on the transition to sustainable food and agricultural systems (FAO 2019b), calls for an explicit focus on the social and economic dimensions of food systems, with a strong focus on the rights of women, youth and indigenous peoples. Cross-disciplinary conversations are essential to integrating specialist insights on food and agriculture sectoral practices, with general insights from the fields of social innovation, and social entrepreneurship.

Even when innovation systems are studied in more detail, sustainability transitions are studied as functionalist approaches that dictate prescriptive (e.g. Loorbach 2010) or ontological lenses (e.g. Geels 2010), but tend to neglect normative and ethical dimensions (Schaile et al. 2017). For example, when viewed from a scientific and technical perspective, agroecology has been defined as the "application of ecological concepts and principles to farming systems, focusing on the interactions between plants, animals, humans and the environment, to foster a sustainable agricultural development that ensures FSN" (HLPE 2016). Normative dimensions, however, deeply influence the directionality, legitimacy, responsibility, and their interrelations in innovation systems. Stakeholders have conflicting visions, interests, norms, and expectations, and sustainability transition research that adopts a narrow functionalist approach ignores these norms at its own peril. In line with this caution, the FAO acknowledged that "today's more transformative visions of agroecology integrate transdisciplinary knowledge, farmers' practices and social movements while recognizing their mutual dependence" (HLPE 2019, p. 31), and called for research into broader conceptions of the term. Resource-dependencies further weaken the resilience of food systems (Schipanski et al. 2016; Puma et al. 2015). In practice, social finance is fragmented (Haveman and Negra, this issue). The acquisition and continued provision of financial resources (e.g. impact capital, development finance, government financing) is often siloed, with different regional and sectoral priorities, appetites for risk, temporal horizons, and approaches to impact. Without models of capital that work together for all-including women, youth and indigenous peoples, systemic transformations are weakened, and words like 'transition', 'sustainability' and 'innovation' form a coercive rhetoric that perpetuates the political and institutional interests of a powerful few (Voss and Kemp 2006).

The consequences of these niche, functionalist, and resource-dependent perspectives on sustainability transitions are severe. At the policy arena (global and local), transformation of food and agricultural systems is often advocated by scientific communities and implemented through research-led, top-down architectures, with little input from consumers and farmers (Cerf et al. 2012; Prost et al. 2017). Where innovations and sustainability have been recognized in food policy agendas, formulating effective policies remain a daunting challenge (Fukasaku 2005). Emerging agricultural entrepreneurship and alternative agri-food initiatives are dismissed as local niche events if successful, and blamed for not being 'real transition events' if the initiative fails to scale sufficiently to influence the existing regime (Beckie et al. 2012). In contrast, business research on innovation and entrepreneurship emphasizes the role of messy, humancentered action within organizations and nations (Davidsson et al. 2006; Wong et al. 2005; Mason and Brown 2014). Policies that encourage entrepreneurial ecosystems, tend to urge similarly cross-functional and cross-sectoral interactions (see Cavallo et al. 2019 for a review), as recent policies for sustainability transitions (Loorbach et al. 2017; Kivimaa and Kern 2016).

This special issue responds to the call for reflexive research on 'sustainability transitions', and offers 
contributions from a wide set of disciplines. By integrating normative perspectives into functional mechanisms of sustainability transition, this issue takes up Schaile et al.'s (2017) call to study innovation systems beyond the technological dimension. In line with agroecological approaches that have broadened in recent years to focus on whole agrifood systems, and not only farming systems (Thompson and Scoones 2009), this issue goes beyond separating scientific and technical dimensions of agroecology from the social and political dimensions, and embraces a transdisciplinary outlook. The main goal of the special issue is to engage a community of social entrepreneurs, ecosystem players and researchers to contribute analytical methods, experiences and scientific insights on emerging social innovations related to food, agriculture and rural-urban transformation.

\section{The Covid-19 pandemic and implications for sustainability transition}

The COVID-19 pandemic has stressed many parts of the agri-food industry-from supply chains, production and retail (WFP 2020; FAO 2020a). The pandemic has also stressed local food systems that may not have the capacity or labor to respond to growing needs (Woodhill 2020; FAO 2020b; ARC 2020). The pandemic, in other words, will have long-lasting macroeconomic effects. In the context of these systemic societal challenges, neither global agricultural systems nor local food networks may be enough to create environmentally sustainable or economically resilient food-systems. We consider the specific challenges brought on by the pandemic, and the implications for sustainability transition.

\section{Effects on supply chains, production and retail}

The main challenges in food and nutrition security are around food delivery (FAO 2020a, b, c), and availability (WFP 2020) as shelves are not restocked due to supplychain distribution slowdowns (FOLU 2020). Subsequent challenges in food production continue as a proportion of producers (farmers and food processing workers) fall ill, and farms and processing plants are shut down. Migrant farm workers and laborers are stopped at regional borders as countries enforce border shutdowns with the hope of preventing the further spread of the pandemic (IOM 2020). These, and other travel restrictions when coupled with the closing of small and medium enterprises (SMEs), result in severe labor shortages that affect the production of food, and deplete incomes for the service sector, for day-laborers, and for broad swaths of the population at large (HLPE 2020, p. 3).
While the agri-food industry may see an initial surge in business for pre-packaged foods, shelf-stable foods, and other fast-moving consumer goods (FMCGs), distribution challenges create uncertainties in the supply-chain (HLPE 2020 , p. 4). From a food and health perspective, the move toward shelf-stable, processed, packaged foods is often less nutritious than fresh-food alternatives (HLPE 2020, p. 5). In contrast, in less industrialized countries, individuals in these situations are likely to spend more time on food harvesting and preparation, likely leading to less economic productivity (Laborde et al. 2020).

\section{Effect on macroeconomic indicators}

Countries that are net food importers may not gain access to sufficient supplies, and subsequently food prices may increase (WFP 2020). For countries that are commodity/ mineral/oil exporters, foreign currency reserves may be rapidly depleted due to manufacturing and productivity slowdowns, that in turn, lead to an unfavorable balance of trade (WFP 2020, p. 6). Economic challenges may extend to wealthier countries as well, as they extend social safety programs through cash transfers and subsidies (WFP 2020, p. 11). Countries that can, will extend social safety programs through cash transfers and subsidies, which can further increase debt ratios (OECD 2020a). Global financial organizations (e.g. World Bank, OECD), project a general decrease in global economic output with East Asia and the Pacific in need of an immediate stimulus (World Bank $2020 \mathrm{~b}$ ), and with global GDP growth hovering around $0 \%$ for 2020 (OECD 2020b).

\section{Implications for the sustainable transition of food and agriculture systems}

Transforming 'modern' agriculture into a system that offers FSN and a healthy natural environment is challenging. Much more so during a pandemic. Prior attempts at change have tended to reinforce systemic 'lock-ins' (FAO 2019c; Makard et al. 2012), and indicate the importance of research into 'sustainability transition'. For a long time, agricultural innovations were viewed as extension processes of scientific knowledge through a knowledge architecture of hierarchy (i.e. research-education-extension), and such an intellectual deeply shaped the policy agenda towards science, technology and R\&D (Collinson 2000; OECD 2012). The success of the model was context specific to a homogenous production environment, large commercial farm units and stable economic conditions. The growing dependency on external actors in modern agriculture are leaving the subjects of public concern, given the emerging interaction with social and environmental context (Darnhofer et al. 2012). The reconfiguration of food and agriculture system distinguishes 
itself from controlling processes, planning, standardization, constancy and predictability, characterizing as a dynamic, adaptive, uncertain and complex system. Transition in such a system features socio-technical interactions and goes beyond sectoral approaches (Geels 2004).

\section{The role of alternative food networks (AFNs)}

The uncertainties and stressors on industrial supply-chains, cast light on alternative agri-food movements that have been an emerging part of public consciousness, and flourish locally in many parts of the world. These movements, which take on a variety of forms, such as "fair trade", "organic", "agroecology" and "food sovereignty" advocate for social justice and rights to healthy and ecologically appropriate food production and sustainability through innovative methods (Agarwal 2014; Edelman 2014; Misra 2018). These concepts often move beyond a focus on food security-access to sufficient food-to advocate access to knowledge, capacity and resources (Alkon and Mares 2012). Some of these movements explicitly oppose neoliberalism and industrial food systems (radicalism) while some propose deliberative reconfiguration within the system (reformism) (RomanAlcalá 2017).

\section{Limitations of AFNs}

Critiques to alternative agri-food movements question the movements' immediate relevance, their capacities to scale, and internal philosophical coherence. For example, very few movements address immediate problems (such as hunger, malnutrition and degraded natural resources) while working towards structural changes needed for sustainable and democratic food systems (Martiniello 2015). In addition, the changes brought about through local practice are often small, and hard to scale toward lasting, transformative institutions or social structures (Alonso-Fradejas et al. 2015; Fairbairn 2012; Hinrichs 2003). Alternative agrifood movements (farmers markets, organic grocery stores, CSAs) are also critiqued for being inconsistent with social justice, as the practices inadvertently reproduce exclusions and run the risk of "defensive localism" (Winter 2003).

\section{Agriculture and human values and agri-food transformation}

Agriculture and Human Values has critically examined the conflicts and contradictions within contemporary agricultural food systems and the impact of policies, institutions and practices on innovative production, process and empowerment relating with the agrifood transformation. In 2012, the journal convened a special issue to reflect the global debates on alternative food regime and the critiqued concept of 'food security' (Anderson and Bellows 2012). In 2015, the journal organized another special issue about Community Support Agriculture (CSA), an alternative food network that endorses local supply of agricultural produces and implicates contracts and trust between consumers and producers (Lagane 2015). The journal convened a special issue in 2016 to understand the relationship between discourses on food security and those on food sovereignty and food justice, with a symposium titled "From Food Security to the Enactment of Change" (Piatti and Dwiartama 2016). The journal has also been quick to recognize agriculture as a "financial asset class", and has documented the contemporary process of financialization in global food and agricultural markets over the past decade and the blurring of sectoral boundaries (Clapp et al. 2017).

These continuing endeavors deepen our knowledge of what it takes to transform agrifood systems. Perhaps even more starkly, these initiatives also highlight knowledge gaps that need to be bridged across stakeholders in the food system: from entrepreneurs to companies, investors and policy makers. Discourses on agriculture as an asset class (Clapp et al. 2017) remain disconnected from a unified approach to innovative social finance and the emerging asset classes of impact investment, pay-for-success and other result-oriented investment instruments ( $\mathrm{O}^{\prime}$ Donohue et al. 2010). Food sovereignty and alternative food networks are cross-cutting issues that need multidisciplinary conversations. Without these dialogues, the discourse of alternative food systems run the risk of being seen as 'anti-business' and gets confounded with political praxis, limiting the potential for transformation (Anderson and Dees 2006).

Emerging and flourishing practices of alternative food networks appeal to a wide range of thematic issues in different research fields including social entrepreneurship, impact investment, development and social finance, and socially responsible investment. In particular, the social innovations and financing mechanisms mentioned in the food system literature, are extensively explored in fields that study organizational theory, social entrepreneurship, finance, and management (Fayolle and Matlay 2010). To bridge the gap between the research fields of social entrepreneurship and development economics, there is a pressing need to promote collaboration between academic colleagues of different fields and practitioners and encourage conversations that cast a broad net. In response to this need, the Swiss Agency for Development and Cooperation (SDC) organized a symposium on "Social Entrepreneurship and Innovative Finance for Rural-Urban Transformation" in October 2018 in Beijing. 


\section{The special issue: social innovation and sustainability transition}

The symposium highlighted the need to understand social innovation as a set of multi-level mechanisms that facilitate sustainability transitions: across sectors, across social finance, across institutional structures, and through social ventures across geographic regions. This special issue is an outgrowth of that initial conversation between the fields of food systems research, policy, and entrepreneurship and social innovation. Scholars who answered the call for papers adopted a variety of perspectives on mechanisms of sustainability transition.

\section{Social innovation across rural-urban landscapes}

Jia and Desa (this issue), draw from an extensive literature review on social entrepreneurship, to place the symposium discussion within the context of research. The symposium tapped into a broad range of contemporary issues in the field-from pluralistic definitions and ecosystems of social entrepreneurship, mechanisms of social change (in the context of rural-urban transformation) to measuring and metrics of social impacts, and the landscape of impact investment. Symposium participants viewed social entrepreneurship as a process-based approach to enduring, social and environmental change, in which the balance between social mission and market approaches depended upon the social sector, and geopolitical region under consideration. The following articles elaborate on social innovation and transitions in a variety of sectors and regions.

\section{Transitions across AFN's: from local to regional}

Tezcan et al. (this issue), in a detailed comparative study of CSA's in Wales, offer us a hopeful vision toward 'workable utopias' built on social inclusion and empowerment. By exploring sources of social innovation: social economy, collective action, social movements and direct public policy, the authors study how Welsh CSA's address three main dimensions of social innovation: (a) the product-in responding to and satisfying alienated needs, (b) community empowerment-by increasing socio-political capabilities and access to resources, and (c) the process dimensions that change governance relations. In so doing, the authors explore the steps needed to transfer these local social innovations into scalable utopias, and identify the limitations that prevent AFNs from replicating, participating in policies, and decision-making at macro level.

\section{Transitions across values embedded in social innovations}

Chowdhury (this issue) studies the process of transferring social innovations from one region to another, across differences in country, and from urban to rural environments. In a longitudinal study of the transfer of eyecare from a social venture in India, to two different social ventures in Paraguay, the author reflects upon two often-mentioned dimensions that motivate social innovation: the social mission, and the economic proposition, and points to yet another mechanism, the role of the spiritual. The study emphasizes the role of values as super-ordinate to economic and social mission in facilitating an effective innovation transfer and poses a key reminder for researchers not to discount the roles of the spiritual and values-based logics when studying mechanisms of social innovation.

\section{Transitions across social finance mechanisms}

In the case of agriculture as a financial asset class, knowledge gaps surrounding financing mechanisms and subsequent transfers of social innovation limit the investments and entrepreneurial potential of the private sector. This fragmented financing landscape is especially stark, when we look at the resource gap-a "billions-to-trillions" 3 challenge, that will require financing mechanisms that facilitate resource transfer from the private sector, increase effectiveness and accountability. As a symptom and consequence of this fragmentation, alternative mechanisms of finance (e.g. impact investment and blended finance) are appearing across the landscape of development finance. In 2017, $\$ 228$ billion was under private management with the intention to generate social and environmental impact alongside a financial return (GIIN 2018). More than half (about 57\%) of the impact investment deals were conducted through a strategic use of development finance and philanthropic funds to mobilize private capital flows to emerging and frontier markets, termed as "blended finance" (GIIN 2018; WEF \& OECD 2015). Havemann and Negra (this issue) address this core issue of blended finance and illustrate that all financing mechanisms are not equivalent, with different institutional priorities, constraints, risk tolerances, and sectoral preferences.

\footnotetext{
${ }^{3}$ While conventional development finance (from developed countries to developing countries) totaled less than USD 150 billion in 2016 (OECD, 2017a, b), studies suggest that eradicating global poverty in line with the Sustainable Development Goals (SDGs) will require additional investments of much as $\$ 2.5$ trillion per year (Sachs and Schmidt-Traub 2014).
} 


\section{Transitions across institutional structures}

Jia (this issue) studies nascent landscapes of social entrepreneurship in China, and identifies a variety of fragmented institutional and resource-based limitations that hinder the growth of effective enterprises. Drawing upon a multi-level perspective of the social innovation landscape, that includes multiple niches with small yet innovative ventures, and larger established regimes-institutional structures with access to resources but limited social innovation 'deal-flow', the author offers guidance for social finance that is appropriate for ventures at various stages of growth and development, and also offers suggestions for institutional structures that facilitate certification and further legitimation of social innovations. In so doing, the study adopts a wide lens of social innovation, and encourages business and innovation ecosystems that emphasize shared value.

\section{Social innovation and systemic impact: a call to transdisciplinary action}

$55 \%$ of the world's population live in urban areas, and that proportion may increase to $68 \%$ by 2050 (United Nations 2018). The sustainable transitions of food and agriculture systems is a pressing issue, and from a macro-economic perspective, the Covid-19 pandemic increases the potential of social crisis in economically fragile countries (WFP 2020). Asia, for example, is home to $54 \%$ of the world's urban population. Declines in economic output, local incomes and/ or food scarcity will prompt further global migrations that stress health care systems and environmental ecosystems (Pearce 2020; Hepburn et al. 2020).

Sustainability transition in food and agriculture need a broader lens than the mere application of innovation and entrepreneurship into food and agriculture subsystems. The process needs a) social and cultural changes that embrace multiple trajectories and pathways (FAO 2019c, and b) systemized interactions of scientific interpretations and symbolic meanings of technologies, and relating institutions (Darnhofer et al. 2012). This calls for a reflexive understandings of shifts in knowledge regime and design practices (Barbier and Elzen 2012; Voss et al. 2006).

The challenges ahead require new regulations, new behaviors, cultural change, and institutional 'hybridity' (Allaire and Wolf 2004). Transdisciplinary research is challenging-requiring the corralling of diffuse research interests and research questions, translations of discipline-specific empirical methods, field-specific research methodologies, and a variety of literatures (Brandt et al. 2013; Bunders et al. 2015; Lang et al. 2012). Transdisciplinary research may also fall into the forgotten-middle (MacCleave 2006; Baker 2006) between specialized disciplines. Innovation and transition may be rhetorically hollow to researchers in agricultural science. Business researchers, in contrast, may view the focus on food and agriculture as an esoteric contextual domain with little application to theory or practice. However, such transdisciplinary conversations can also foreshadow nascent collaborations across pre-paradigmatic fields, new research streams, and re-prioritize the normative, as glimpsed over the twenty-year evolution of social entrepreneurship research (Kraus et al 2014).

Sustainability transitions that accompany migrations between rural and urban areas will not occur naturally and equally. While urbanization creates employment and entrepreneurial opportunities (Cook et al. 2001; Pingali 2007; Reardon and Barrett 2000), social returns to migration may be less than private returns with distributional consequences being less than optimum (Mazumdar 1987). Questions abound as food systems struggle to meet the needs of appetites that are urbanized and globalized. As the pandemic exacerbates patterns of rural-urban transformation, we need new opportunities for social service delivery in agriculture and rural economy. Researchers, policy makers and entrepreneurs trying to understand these enduring challenges are invited to partake in transdisciplinary conversations-on social innovation, finance, and impact within this fundamental context of agriculture, ecology and human values.

Acknowledgement The authors are thankful to research funding from National Natural Science Foundation of China (71573209; $71661147001)$ and China National Social Science Foundation (16ZDA021).

\section{References}

Agarwal, Bina. 2014. Food sovereignty, food security and democratic choice: Critical contradictions, difficult conciliations. Journal of Peasant Studies 41: 1247-1268.

Alkon, Alison Hope, and Teresa Marie Mares. 2012. Food sovereignty in US food movements: Radical visions and neoliberal constraints. Agriculture and Human Values 29: 347-359.

Allaire, G., and S. Wolf. 2004. Cognitive representations and institutional hybridity in agrofood systems of innovation. Science, Technology and Human Values 29: 431-458.

Alonso-Fradejas, Alberto, Saturnino M. Borras, Todd Holmes, Eric Holt-Giménez, and Martha Jane Robbins. 2015. Food sovereignty: Convergence and contradictions, conditions and challenges. Third World Quarterly 36: 431-448.

Anderson, Molly D., and Anne C. Bellows. 2012. Introduction to symposium on food sovereignty: Expanding the analysis and application. Agriculture and Human Values 29: 177-184.

Anderson, B.B., and J.G. Dees. 2006. Rhetoric, reality, and research: Building a solid foundation for the practice of social entrepreneurship. In Social entrepreneurship, new models of sustainable social change, ed. A. Nicholls. New York: Oxford University Press.

ARC. 2020. Coping with Covid19-The open food network and the new digital order(s). https://www.arc2020.eu/coping-with-covid 19-open-food-network-and-new-digital-orders/. Accessed 29 May 2020. 
Baker, L.A. 2006. Perils and pleasures of multidisciplinary research. Urban Ecosystems 9 (1): 45-47.

Barbier, M., and B. Elzen. 2012. System innovations, knowledge regimes, and design practices towards transitions for sustainable agriculture. Paris: Inra.

Beckie, Mary A., Emily Huddart Kennedy, and Hannah Wittman. 2012. Scaling up alternative food networks: Farmers' markets and the role of clustering in western Canada. Agriculture and Human Values 29: 333-345.

Brandt, P., A. Ernst, F. Gralla, C. Luederitz, D.J. Lang, J. Newig, F. Reinert, D.J. Abson, and H. Von Wehrden. 2013. A review of transdisciplinary research in sustainability science. Ecological Economics 92: 1-15.

Bunders, J.F., A.E. Bunders, and M.B. Zweekhorst. 2015. Challenges for transdisciplinary research. Global sustainability, 17-50. New York: Springer.

Buurma, Jan, Anne-Charlotte Hoes, Karel de Greef, and Volkert Beekman. 2017. Role of NGOs in system innovation towards animal friendly pork production in the Netherlands. In AgroEcological transitions: Changes and breakthroughs in the making, ed. Boelie Elzen, Anna Augustyn, Marc Barbier, and Barbara Van Mierlo. Gelderland: Wageningen University \& Research, Applied Arable and Vegetable Research.

Cassidy, E., and A. Snyder. 2019. Map of the month: How many people work in agriculture? http://blog.resourcewatch.org/2019/05/30/ map-of-the-month-how-many-people-work-in-agriculture/. Accessed 29 May 2020

Cavallo, A., A. Ghezzi, and R. Balocco. 2019. Entrepreneurial ecosystem research: Present debates and future directions. International Entrepreneurship and Management Journal 15 (4): 1291-1321.

Cerf, M., M.H. Jeuffroy, L. Prost, and J.M. Meynard. 2012. Participatory design of agricultural decision support tools: Taking account of the use situations. Agriculture for Sustainable Development 32: 899-910.

Clapp, Jennifer, S. Ryan Isakson, and Oane Visser. 2017. The complex dynamics of agriculture as a financial asset: Introduction to symposium. Agriculture and Human Values 34: 179-183.

Collinson, M. 2000. A history of farming systems research. Oxon: CABI.

Cook, M.L., T. Reardon, C. Barrett, and J. Cacho. 2001. Agroindustrialization in emerging markets: Overview and strategic context. International Food and Agribusiness Management Review 2: 277-288.

Darnhofer, Ika, David Gibbon, and Benoit Dedieu. 2012. Farming systems research: an approach to inquiry. In Farming systems research into the 21st century: The new dynamic, ed. Ika Darnhofer, David Gibbon, and Benoit Dedieu, 3-31. Dordrecht: Springer.

Davidsson, P., F. Delmar, and J. Wiklund. 2006. Entrepreneurship and the growth of firms. Cheltenham: Edward Elgar Publishing.

Djanian, M., and N. Ferreira. 2020. Agriculture trends disrupting the food value chain I McKinsey. https://www.mckinsey.com/indus tries/agriculture/our-insights/agriculture-sector-preparing-fordisruption-in-the-food-value-chain. Accessed 29 May 2020

Edelman, Marc. 2014. Food sovereignty: Forgotten genealogies and future regulatory challenges. Journal of Peasant Studies 41: 959-978.

Fairbairn, Madeleine. 2012. Framing transformation: The counterhegemonic potential of food sovereignty in the US context. Agriculture and Human Values 29: 217-230.

FAO. 2018. Transforming food and agriculture to achieve the SDGs: 20 interconnected actions to guide decision-makers. https://www.fao. org/3/I9900EN/i9900en.pdf. Accessed 29 May 2020

FAO. 2019b. Sustainable food systems: Concept and framework. https ://www.fao.org/3/ca2079en/CA2079EN.pdf. Accessed 29 May 2020
FAO. 2019a. Global trends in GDP, agriculture value added, and food-processing value added (1970-2017). https://www.fao. org/economic/ess/ess-economic/gdpagriculture/en/. Accessed 29 May 2020

FAO. 2019c. The 10 elements of agroecology. guiding the transition to sustainable food and agricultural systems. https://www.fao.org/ agroecology/knowledge/10-elements/en/. Accessed 29 May 2020

FAO. 2020a. Keeping food and agricultural systems alive-Analyses and solutions in a period of crises-COVID-19 Pandemic. https ://www.fao.org/2019-ncov/analysis/en/. Accessed 29 May 2020

FAO. 2020b. COVID- 19 and smallholder producers' access to markets. https://www.fao.org/3/ca8657en/CA8657EN.pdf. Accessed 29 May 2020

Fayolle, Alain, and Harry Matlay. 2010. Social entrepreneurship: A multicultural and multidimensional perspective. In Handbook of research on social entrepreneurship, ed. Alain Fayolle and Harry Matlay, 1-14. Cheltenham, UK: Edward Elgar.

FOLU. 2019. Growing better: Ten critical transitions to transform food and land use. Food and land use coalition. https://www.foodandlan dusecoalition.org/global-report/. Accessed 29 May 2020

FOLU. 2020. A call to action for world leaders. food and land use coalition. https://www.foodandlandusecoalition.org/a-call-to-actio n-for-world-leaders/. Accessed 29 May 2020

Fukasaku, Yukiko. 2005. The need for environmental innovation indicators and data from a policy perspective. In Towards environmental innovation systems, ed. Matthias Weber and Jens Hemmelskamp. Heidelberg: Springer.

Geels, Frank W. 2004. From sectoral systems of innovation to sociotechnical systems Insights about dynamics and change from sociology and institutional theory. Research Policy 33: 897-920.

Geels, Frank W. 2010. Ontologies, socio-technical transitions (to sustainability), and the multi-level perspective. Research Policy 39: 495-510.

GIIN. 2018. Annual Impact Investor Survey (8th edn). Global Impact Investing Network.

GNR. 2020. The 2020 Global Nutrition Report in the context of Covid-19. https://globalnutritionreport.org/reports/2020-globa 1-nutrition-report/2020-global-nutrition-report-context-covid-19/. Accessed 29 May 2020

Hawken, P. 2017. Drawdown: The most comprehensive plan ever proposed to reverse global warming. New York: Penguin.

Heisey, P., and K. Fuglie. 2018. Agricultural research investment and policy reform in high-income countries. ERR-249. U.S. Department of Agriculture, Economic Research Service; World Bank data, Global GDP.

Hepburn, C., B. O'Callaghan, N. Stern, J. Stiglitz, and D. Zenghelis. 2020. Will COVID-19 fiscal recovery packages accelerate or retard progress on climate change? Oxford Review of Economic Policy, 36.

Hinrichs, C.Clare. 2003. The practice and politics of food system localization. Journal of Rural Studies 19: 33-45.

HLPE. 2016. Sustainable agricultural development for food security and nutrition: what roles for livestock? A report by the high level panel of experts on food security and nutrition of the committee on world food security. Rome. https://www.fao.org/3/a-i5795 e.pdf. Accessed 29 May 2020

HLPE. 2019. Agroecological and other innovative approaches for sustainable agriculture and food systems that enhance food security and nutrition. https://www.fao.org/3/ca5602en/ca5602en.pdf. Accessed 29 May 2020

HLPE. 2020. Impact of COVID-19 on food security and nutrition (FSN). https://www.fao.org/fileadmin/templates/cfs/Docs1920/ Chair/HLPE_English.pdf. Accessed 29 May 2020

Houngbo. 2020. What's needed to protect food security in Africa during COVID-19. https://www.ifad.org/en/web/latest/blog/asset /41945191. Accessed 29 May 2020 
IOM. 2020. Covid-19: Policies and impact on seasonal agricultural workers, UN International Office of Migration, Issue Brief. https ://www.iom.int/sites/default/files/documents/seasonal_agricultur al_workers_27052020_0.pdf. Accessed 29 May 2020

IPCC. 2019. Climate change and land. An IPCC Special Report on climate change, desertification, land degradation, sustainable land management, food security, and greenhouse gas fluxes in terrestrial ecosystems. https://www.ipcc.ch/site/assets/uploa ds/2019/08/4.-SPM_Approved_Microsite_FINAL.pdf. Accessed 29 May 2020

Kivimaa, P., and F. Kern. 2016. Creative destruction or mere niche support? Innovation policy mixes for sustainability transitions. Research Policy 45 (1): 205-217.

Kraus, S., M. Filser, M. O'Dwyer, and E. Shaw. 2014. Social entrepreneurship: An exploratory citation analysis. Review of Managerial Science 8 (2): 275-292.

Laborde, D., W. Martin, and R. Vos. 2020. Poverty and food insecurity could grow dramatically as COVID-19 spreads I IFPRI : International Food Policy Research Institute. https://www.ifpri.org/blog/ poverty-and-food-insecurity-could-grow-dramatically-covid-19spreads. Accessed 29 May 2020

Lagane, J. 2015. Introduction to the symposium: Towards cross-cultural views on Community Supported Agriculture. Agriculture and Human Values 32: 119-120.

Lang, D.J., A. Wiek, M. Bergmann, M. Stauffacher, P. Martens, P. Moll, M. Swilling, and C.J. Thomas. 2012. Transdisciplinary research in sustainability science: Practice, principles, and challenges. Sustainability Science 7 (1): 25-43.

Loorbach, Derk. 2010. Transition management for sustainable development: A prescriptive, complexity-based governance framework. Governance: An international journal of policy. Administration, and Institutions 23: 161-183.

Loorbach, D., N. Frantzeskaki, and F. Avelino. 2017. Sustainability transitions research: Transforming science and practice for societal change. Annual Review of Environment and Resources 42: 599-626.

MacCleave, A. 2006. Incommensurability in cross-disciplinary research: A call for cultural negotiation. International Journal of Qualitative Methods 5 (2): 40-54.

Markard, J., R. Raven, and B. Truffer. 2012. Sustainability transitions: An emerging field of research and its prospects. Research policy 41 (6): 955-967.

Martiniello, Giuliano. 2015. Food sovereignty as praxis: Rethinking the food question in Uganda. Third World Quarterly 36: 508-525.

Mason, C., and R. Brown. 2014. Entrepreneurial ecosystems and growth-oriented entrepreneurship. Final Report to OECD, Paris 30 (1): 77-102.

Mazumdar, Dipak. 1987. Rural-urban migration in developing countries. In Handbook of regional and urban economics, ed. E.S. Mills. New York: Elsevier.

Misra, Manoj. 2018. Moving away from technocratic framing: Agroecology and food sovereignty as possible alternatives to alleviate rural malnutrition in Bangladesh. Agriculture and Human Values 35: 473-487.

O’Donohue, N., C. Leijonhufvud, Y. Saltuk, A. Bugg-Levine, and M. Brandenburg. 2010. Impact investments: An emerging asset class. https://assets.rockefellerfoundation.org/app/uploads/2010112913 1310/Impact-Investments-An-Emerging-Asset-Class.pdf.

OECD. 2012. Improving agricultural knowledge and innovation systems: OECD conference proceedings. Paris: OECD Publishing.

OECD. 2017a. Development aid rises again in 2016 but flows to poorest countries dip. https://www.oecd.org/dac/development-aid-rises -again-in-2016-but-flows-to-poorest-countries-dip.htm. Accessed 11 Oct 2018

OECD. 2017b. Global private philanthropy for development. https ://www.oecd.org/dac/financing-sustainable-development/devel
opment-finance-standards/Philanthropy-Development-Survey.pdf. Accessed 13 Nov 2018

OECD. 2020. OECD economic outlook, interim report march 2020. OECD Publishing, Paris, . https://doi.org/10.1787/7969896b-en.

Pearce, F. 2020. After the Coronavirus, two sharply divergent paths on climate. Yale E360. https://e360.yale.edu/features/after-thecoronavirus-two-sharply-divergent-paths-on-climate. Accessed 29 May 2020

Piatti, Cinzia, and Angga Dwiartama. 2016. From food security to the enactment of change: Introduction to the symposium. Agriculture and Human Values 33: 135-139.

Pingali, Prabhu. 2007. Westernization of Asian diets and the transformation of food systems: Implications for research and policy. Food Policy 32 (33): 281-298.

Prost, Lorène, Elsa T.A. Berthet, Marianne Cerf, Marie-Hélène Jeuffroy, Julie Labatut, and Jean-Marc Meynard. 2017. Innovative design for agriculture in the move towards sustainability: Scientific challenges. Research in Engineering Design 28: 119-129.

Puma, M.J., S. Bose, S.Y. Chon, and B.I. Cook. 2015. Assessing the evolving fragility of the global food system. Environmental Research Letters 10 (2): 024007.

Reardon, Thomas, and Christopher B. Barrett. 2000. Agroindustrialization, globalization, and international development: An overview of issues, patterns, and determinants. Agricultural Economics 23: 195-205.

Roman-Alcalá, Antonio. 2017. Looking to food sovereignty movements for postgrowth theory. Theory \& Politics in Organization 17: 119-145.

Sachs, J and G. Schmidt-Traub. 2014. Financing sustainable development: Implementing the SDGs through effective investment strategies and partnerships: UNCTAD: World Investment Report 2014. Investing in the SDGs: An Action Plan

Schipanski, M.E., G.K. MacDonald, S. Rosenzweig, M.J. Chappell, E.M. Bennett, R.B. Kerr, et al. 2016. Realizing resilient food systems. BioScience 66 (7): 600-610.

Schlaile, Michael P., Sophie Urmetzer, Vincent Blok, Allan Dahl Andersen, Job Timmermans, Matthias Mueller, Jan Fagerberg, and Andreas Pyka. 2017. Innovation systems for transformations towards sustainability? Taking the normative dimension seriously. Sustainability 9: 1-20.

Thompson, J., Scoones, I. (2009). Addressing the dynamics of agrifood systems: an emerging agenda for social science research. EnvironmentalScience and Policy, 12(4): 386-397.

United Nations. 2018. 68\% of the world population projected to live in urban areas by 2050 , says UN. https://www.un.org/developmen t/desa/en/news/population/2018-revision-of-world-urbanizationprospects.html. Accessed 18 July 2018

van Nieukoop, M. 2019. Do the costs of the global food system outweigh its monetary value? https://blogs.worldbank.org/voices/docosts-global-food-system-outweigh-its-monetary-value. Accessed 29 May 2020

Voss, Jan-Peter, Dierk Bauknecht, and René Kemp. 2006. Reflexive governance for sustainable development. Cheltenham: Edward Elgar.

Voss, Jan-Peter, and René Kemp. 2006. Sustainability and reflexive governance: Introduction. In Reflexive governance for sustainable development, ed. Jan-Peter Voß, Dierk Bauknecht, and René Kemp. Cheltenham: Edward Elgar.

WEF \& OECD. 2015. Blended finance vol. 1: A primer for development finance and philanthropic funders. Paris: World Economic Forum \& OECD

WFP. 2020. COVID-19-Potential impact on the world's poorest people. https://www.wfp.org/publications/covid-19-potential-impac t-worlds-poorest-people. Accessed 29 May 2020

Winter, Michael. 2003. Embeddedness, the new food economy and defensive localism. Journal of Rural Studies 19: 23-32. 
Wong, P.K., Y.P. Ho, and E. Autio. 2005. Entrepreneurship, innovation and economic growth: Evidence from GEM data. Small business economics 24 (3): 335-350.

Woodhill. 2020. Responding to the impact of COVID-19 on rural people and food systems. https://www.foresight4food.net/wp-conte nt/uploads/2020/05/Impact-of-COVID-19-on-Rural-Poverty-andFood-Systems-V2.pdf. Accessed 29 May 2020

World Bank. 2020a. Employment in agriculture (\% of total employment) (modeled ILO estimate). International Labour Organization, ILOSTAT database. https://data.worldbank.org/indicator/ SL.AGR.EMPL.ZS. Accessed 29 May 2020

World Bank. 2020b. World Bank East Asia and Pacific Economic Update, April 2020: East Asia and Pacific in the Time of COVID19. Washington, DC: World Bank. https://openknowledge.world bank.org/handle/10986/33477. Accessed May 292020.

Publisher's Note Springer Nature remains neutral with regard to jurisdictional claims in published maps and institutional affiliations. questions: How do social innovations scale and have social impact? Under what conditions does academic learning drive social change? His research adds empirical evidence to the literature on social innovation at the international and local level, and to the pedagogical literature that emphasizes critical thought and learning. He teaches classes at the intersection of business, innovation for sustainability and climate adaptation.

Xiangping Jia is a professor at the Agricultural Information Institute, Chinese Academy of Agricultural Sciences. He received his $\mathrm{PhD}$ from University of Hohenheim, Germany. Working on research about agricultural policies and rural development, he has broad interest in the application of new institutional economics to the issues of agri-food market coordination, development of inclusive financial markets, the organization of smallholder farms, knowledge transfer and innovation, and agricultural extension system. At present, he researches innovative institutions that align agricultural universities with stakeholders such as public extension systems and private sectors for a resilient farm system.

Geoffrey Desa is a professor at San Francisco State University. He received his Ph.D. from the University of Washington, an M.S from Stanford University, and a B.S from Georgia Tech. He follows two 